\title{
IMPLEMENTASI KEBIJAKAN PERLINDUNGAN ANAK JALANAN DI KOTA BANDUNG
}

\author{
Engkus \\ Universitas Islam Negeri (UIN) Sunan Gunung Djati Bandung \\ Email: engkus@uinsgd.ac.id
}

\begin{abstract}
The problem of street children in the city of Bandung is no stranger to the people of Bandung. Moreover, the emergence of street children is due to family poverty. They survive in various ways such as busking, shining shoes, selling newspapers, begging and so on. It is not uncommon for street children to commit criminal acts such as pickpocketing, stealing because they are pressured by the economic situation. The purpose of this study is to describe the implementation of policies on handling street children in Bandung. The method used in this study is a qualitative approach, to reveal more deeply, how the implementation of Law No. 23 of 2002 concerning child protection in the development of street children in the city of Bandung. Data were analyzed descriptively collected through interviews with key informants and ordinary informants in an unstructured or open manner. The results of the study revealed that both community support and the implementation of government policies in tackling street children in the city of Bandung have not been successful. So it can be concluded that the implementation of street child prevention policies in the municipality of Bandung is not optimal.
\end{abstract}

Keywords: Policy Implementation, Street Children, Bandung Municipality.

\section{PENDAHUALUAN}

Indonesia saat ini termasuk salah satu negara besar akan tetapi masih dalam taraf perkembangan atau dapat disebut juga dengan Negara berkembang. Tidak jauh berbeda dengan Negara-negara berkembang lainnya yang ada didunia, Indonesia juga sering menghadapi berbagai macam masalah yang kadang kala bisa menghambat kemajuan Negara tersebut. Salah satu yang paling menjadi sebuah masalah yang serius adalah masalah sosial di kota Bandung. Masalah yang kadang kala punya hubungan dengan budaya di satu daerah ini memang menjadi semacam sebuah virus atau sebuah penyakit yang sering kali kambuh. Misalnya saja ada sebab masalah sosial yang sudah dapat terselesaikan, namun pada sisi yang lain efek dari masalah ini masih ada yang harus ditanggung oleh masyarakat.

Anak merupakan hal yang sangat penting di dalam kehidupan sebuah keluarga, dimana anak tersebut menjadi cikal bakal penerus kehidupan keluarga tersebut, namun pada kenyataannya di lingkungan kita banyak sekali hal yang mengkhawatirkan terjadi pada anak-anak.

http://ejurnal.binawakya.or.id/index.php/MBI
Anak jalanan atau sering disingkat anjal adalah anak yang berusia 5-18 tahun yang menghabiskan sebagian besar waktunya untuk mencari nafkah atau berkeliaran di jalan maupun di tempat-tempat umum. Anak jalanan adalah laki-laki dan perempuan yang menghabiskan sebagian besar waktunya untuk bekerja atau hidup di jalanan dan tempat-tempat umum, seperti pasar, mall, terminal bus, stasiun kereta api, dan taman kota.

Anak jalanan sudah tidak asing lagi untuk masyarakat Kota Bandung. Anak-anak jalanan merupakan anak-anak yang rentan, tergantung, berkembang serta mempunyai kebutuhankebutuhan khusus yang menghabiskan sebagian waktu mereka untuk bekerja di jalanan, pusat keramaian (mall, restoran dan lainnya) baik sebagai pedagang ataupun pengasong, pemulung, pengemis, pengamen, penyemir sepatu, parkir mobil, kuli atau buruh pasar, ojeg payung, dan berkeliaran tidak menentu. Kehidupan anak jalanan tersebut sangat rentan terhadap berbagai macam penyakit dan tindak kekerasan baik anggota kelompoknya atau orang lain. Anak-anak tersebut juga rentan melakukan perbuatan-

Vol.14 No.3 Oktober 2019 
perbuatan yang buruk atau negatif hanya untuk memperoleh sesuap nasi agar dapat bertahan hidup.

Munculnya anak jalanan disebabkan karena faktor kemiskinan keluarganya. Anak jalanan bertahan hidup dengan melakukan aktifitas di sektor informal, seperti mengamen, menyemir sepatu, menjual koran, mengelap kendaraan, memulung barang bekas, mengemis, dan lain sebagainya. Tidak jarang anak jalanan melakukan tindakan kriminal seperti mencopet, mencuri, karena terdesak oleh keadaan ekonomi.

Tabel 1. Data Jumlah Anak Jalanan sebagai Pengemis di Kota Bandung tahun 2012-2017

\begin{tabular}{|c|c|c|}
\hline NO & TAHUN & JUMLAH ANAK \\
\hline 1 & 2012 & 2.162 Orang \\
\hline 2 & 2013 & 1.821 Orang \\
\hline 3 & 2014 & 1.607 Orang \\
\hline 4 & 2015 & 1.520 Orang \\
\hline 5 & 2016 & 1.775 Orang \\
\hline 6 & 2017 & 1.654 Orang \\
\hline
\end{tabular}

Sumber : Data Dinsosnangkis Kota Bandung,2017

Dari jumlah data diatas menunjukkan bahwa jumlah anak jalanan, baik gelandangan ataupun pengemis belum menunjukkan pada angka peningkatan. Tetapi kini sudah lebih dari 80 persen berada di Kota Bandung. Hal ini dilihat dari perhitungan persentase anak jalanan dari tahun ke tahun, yaitu berawal dari tahun 2012 sampai tahun 2017. Persentase pertahun anak jalanan di Kota Bandung ini dapat meningkat ataupun menurun. Biasanya persentase atau perhitungan pertahun anak jalanan adalah sekitar 20 persen atau bahkan sampai 40 persen pertahun. Berdasarkan data tersebut, hasilnya meningkat dan menurun sekitar 30 persen. Jadi, data dan hasil daripada jumlah persentase anak jalanan kurang lebih 80 persen dari perhitungan 100 persen yang menurun hanya sekitar 20 persen jadi hasil akhir daripada persentase anak jalanan di Kota Bandung adalah 80 persen. 80 persen tersebut berjumlah 10.539 anak jalanan di Kota Bandung. Apalagi dalam memasuki bulan ramadhan anak jalanan, gelandangan dan pengemis semakin menjamur di setiap sudut kota Bandung mereka semakin nyaman dengan aktivitasnya dikarenakan pada bulan ramadhan Vol.14 No.3 Oktober 2019 banyak orang ditempat keramaian ataupun pengguna jalan memberikan santunan.

Beberapa masalah yang peneliti temukan di objek penelitian: (1) Jumlah anak jalanan yang bertambah dan tidak diimbangi dengan jumlah anak yang terbina; (2) Masih kurangnya kerjasama Dinas Sosial dan Penanggulangan Kemiskinan Kota Bandung dengan keluarga anak jalanan sehingga menyulitkan perubahan sikap dan pola pikir anak untuk berubah kearah yang lebih baik; (3) Masih kurangnya fasilitas yang dimiliki oleh Dinas Sosial dan Penanggulangan Kemiskinan Kota Bandung.

\section{LANDASAN TEORI Pengertian Administrasi}

(a) Etimologis, Secara etimologis kata administrasi, berasal dari bahasa Latin yang terdiri dari ad + ministrate. Ad artinya intensif, ministrate artinya to serve (melayani), membantu atau memenuhi. Jadi artinya melayani secara intensif. Kemudian terbentuk kata "administratio" (pimpinan), (Engkus, 2017: 5). (b) Historikal, Dilihat dari asal usul kata bahwa administrasi berasal dari bahasa Belanda, pengertian administratie (administrasi dalam arti sempit) kegiatan tata usaha. Walaupun dalam bahasa Belanda sebenarnya mengandung arti yang luas, namun bangsa kita tidak diberi kesempatan memegang jabatan administratif, melainkan bersifat clerical work, sehingga timbulah istilah administrasi dalam arti tata usaha.

Dari bahasa Inggris administrasi, Administration, dengan asal kata kerja to administer artinya to serve (melayani), to manage (mengelola), atau to direct (menggerakkan), dengan demikian dalam arti luas berarti mengelola dan memberikan pelayanan (Engkus, $2017: 5)$.

Selanjutnya diuraikan beberapa definisi administrasi dari para ahli :

(1) Administration may be defined as the organization ad direction of human and material resources to achieve desired ends. (John F Pfiffner, 1960). (Administrasi dapat didefinisikan sebagai organissi dan http://ejurnal.binawakya.or.id/index.php/MBI 
pengarahan sumber daya material dan sumber daya manusia untuk mencapai tujuan-tujuan yang diinginkan).

(2) Administration is conceived as the necessary activities of these individuals (excecutive) in an organization who are change with ordering, forwarding, and faciliating the associate efforts of of group of individuals brought together to realize certain defined purpose. (Ordway Tead,1954). (Administrasi adalah meliputi kegiatan-kegiatan individu (eksekutif) yang penting dalam suatu organisasi yang merubah dengan teratur, memajukan, dan menyediakan fasilitas usaha kerjasama kelompok individu untuk merealisasikan tujuan yang ditentukan).

Menurut Engkus (2017 : 8), ditinjau dari aspek kegiatan administrasi terdapat 4 macam, yaitu: (1) Administrator (orang yang menetapkan); (2) Manajer (orang yang mengendalikan/memimpin usaha); (3) Staf ahli (membantu pemikiran untuk manajer).(4) Worker (orang yang langsung bekerja).

Sedangkan dari ciri-ciri administrasi dapat dilihat dari 3 aspek, (Engkus, 2017 :8) yaitu sebagai berikut :

(1) Sekelompok orang. Adanya orang-orang yang bekerjasama dalam wadah organisasi; (2) Adanya kerjasama. Dalam administrasi kerjasama merupakan bagian yang penting untuk mencapai tujuan bersama; (3) Tujuan, merupakan harapan, sasaran, target, atau pencapaian akhir bersama yang telah ditentukan sebelumnya.

\section{Pengertian Administrasi Publik}

Menurut Pfiffner dan Presthus dalam Syafei (2003: 31) memberikan penjelasan mengenai administrasi negara sebagai berikut: (1) Administrasi Negara meliputi implementasi kebijaksanaan pemerintah yang ditetapkan oleh badan-badan perwakilan politik; (2) Administrasi Negara dapat didefinisikan sebagai koordinasi usahausaha perorangan dan kelompok untuk melaksanakan kebijaksanaan pemerintahan. Hal ini terutama meliputi pekerjaan sehari-hari pemerintah.

\section{Kebijakan Publik}

http://ejurnal.binawakya.or.id/index.php/MBI
Secara umum, istilah "kebijakan" atau "policy" digunakan untuk menunjukkan perilaku seorang aktor (misalnya seorang pejabat, suatu kelompok, maupun suatu lembaga pemerintah) atau sejumlah aktor dalam suatu bidang kegiatan tertentu. Kebijakan memiliki bermacam-macam definisi, dengan demikian perlu dipahami terlebih dahulu batasan yang jelas tentang kebijakan. Secara etimologis, kata kebijakan pemerintah barasal dari Bahasa Inggris yang terdiri dari dua kata yaitu: "policy"dan "publik". Mengenai istilah policy, sampai saat ini belum ada kesepakatan dari para ahli.

\section{Kebijakan Sosial}

Kebijakan sosial dapat diartikan sebagai kebijakan yang menyangkut aspek sosial dalam pengertian sempit, yakni yang menyangkut bidang kesejahteraan sosial. Dimensi sosial ini menyangkut sektor kesejahteraan sosial sebagai suatu bidang atau bagian dari pembangunan sosial atau kesejahteraan rakyat yang bertujuan untuk meningkatkan kualitas kehidupan manusia, terutama mereka yang dikategorikan sebagai kelompok yang tidak beruntung (disadvantaged group) dan kelompok rentan (vulnerable group).

\section{Perlindungan Sosial}

Hingga saat ini terdapat berbagai macam definisi perlindungan sosial. Keragaman ini dipengaruhi oleh kondisi sosial, ekonomi, dan politik suatu negara. Berikut adalah beberapa dari sekian banyak definisi yang digunakan oleh berbagai institusi dan negara.

\section{Konsep Implementasi}

Implementasi adalah suatu tindakan atau pelaksanaan dari sebuah rencana yang sudah disusun secara matang dan terperinci. Implementasi biasanya dilakukan setelah perencanaaan sudah dianggap fix. Berikut disini ada sedikit info tentang pengertian implentasi menurut para ahli.

\section{Anak Jalanan}

Arti anak jalanan menurut peserta Lokakarya Nasional Anak Jalanan dengan Departemen Sosial sebagai penyelenggara adalah "Anak yang sebagian besar menghabiskan waktunya untuk mencari nafkah atau berkeliaran 
di jalanan atau tempat-tempat umum lainnya". (Departemen Sosial, 2006: 22).

\section{METODE PENELITIAN}

Metode penelitian yang digunakan dalam penelitian ini adalah metode kualitatif dengan desain deskriptif, yaitu untuk mendeskripsikan kondisi yang terjadi, menjelaskan proses peristiwa, serta menjawab pertanyaan tentang kondisi yang terjadi terhadap pelaksanaan kebijakan dan implementasi program tersebut. Spesifikasi metode penelitian kualitatif adalah metode yang digunakan untuk meneliti pada kondisi objek yang alamiah, dimana peneliti adalah sebagai instrumen kunci, teknik pengumpulan data bersifat induktif penulisan data dari umum ke khusus dan hasil penelitian kualitatif lebih menekankan makna pada generalisasi objek penelitian kualitatif adalah objek yang alamiah atau natural setting.

Tujuan penelitian kualitatif-deskriptif menggambarkan proses hubungan lengkap baik dalam bentuk verbal atau angka-angka menyajikan informasi dasar peristiwa-peristiwa untuk menciptakan seperangkat kategori dan mengklasifikasikan objek penelitian, menjelaskan seperangkat tahapan atau proses dan tahap selanjutnya untuk menyimpan informasi bersifat menekankan pada makna dari sebuah peristiwa tersebut di atas.

Teknik pengumpulan data yang digunakan oleh peneliti dalam rangka pengumpulan data adalah menggunakan empat metode pengumpulan data: (1) Interview; (2) Observation; (3) the generation and use of documents, and (4) the generation and use of audiovisual methods (Rachmawati, 2017).

Dengan menelaah secara dokumenter, maka peneliti bermaksud melaah realisasi pembangunan nasional sebagaimana digariskan dalam Rencana Pembangunan Nasional (RPN) di tingkat pelaksana (Engkus, 2017).

Informan dalam penelitian ini adalah kepala Dinas Sosial Dan Penanggulangan Kemiskinan Kota Bandung, Kepala Bidang Perlindungan dan Pemberdayaan Sosial, Kepala
Seksi Pemberdayaan, PMKS, dan Masyarakat/ anak jalanan.

\section{HASIL DAN PEMBAHASAN}

Dalam peraturan Undang-undang Nomor 23 Tahun 2002 tentang perlindungan anak, menjelaskan bahwa di Indonesia terdapat beberapa hukum yang mengatur kehidupan masyarakat tetapi dalam pengaplikasiannya sering terjadi ketidakefektifan hukum juga masih banyak terjadi pelanggaran dan manipulasi hukum. Salah satu hukum yang masih belum bisa efektif adalah hukum tentang perlindungan anak. Di Indonesia hal tersebut sudah diatur dalam Undang-undang tersebut dijelaskan pula kewajiban dan tanggung jawab orang tua, keluarga, masyarakat, pemerintah, dan negara untuk memberikan perlindungan pada anak.

Menurut ketentuan yang diatur dalam Undang-undang Nomor 23 Tahun 2002, secara rinci dan jelas telah diatur mengenai langkahlangkah pembinaan yang sejatinya harus dilakukan oleh Pemerintah Kota Bandung (Dinsosnangkis) untuk menangani masalah anak jalanan, gelandangan, pengemis dan pengamen yang semakin bertambah ini. Untuk memperoleh gambaran secara detail mengenai pembinaan yang telah dilakukan selama ini oleh pemerintah Kota Bandung, berikut datanya.

\section{Strategi Pembinaan}

Dengan meruntut ketentuan dalam Undang-undang Nomor 23 Tahun 2002 tentang pembinaan anak jalanan, gelandangan, pengemis dan pengamen di kota Bandung, dapatlah dinyatakan bahwa bentuk pembinaan yang telah dilakukan oleh Pemerintah Kota Bandung sesungguhnya dapat dipetakan (dikelompokkan) ke dalam empat (4) bentuk pembinaan. Keempat bentuk pembinaan yang dimaksudkan adalah :

(1) Pembinaan, yang mencakup tiga langkah pembinaan yaitu, pembinan pencegahan, pembinaan lanjutan, dan usaha rehabilitasi sosial; (2) Pemberdayaan; (3) Bimbingan Lanjutan; (4) Partisipasi Masyarakat. 


\section{Langkah Pembinaan}

Sesungguhnya langkah pembinan ataupun penanganan terhadap anak jalanan telah dilakukan oleh pemerintah Kota Bandung. Semenjak tahun 2008, Pemerintah Kota Bandung telah mencanangkan program pembinaan anak jalanan di wilayah kota Bandung, sebagai perwujudan amanah dari peraturan perundangan berupa Peraturan Undang-undang Nomor 23 Tahun 2002 tentang Pembinaan anak jalanan gelandangan, pengemis dan pengamen di Kota Bandung.

\section{Pembinaan Pencegahan}

Dalam melakukan pembinaan pencegahan, Dinsosnangkis melakukan pendataan terlebih dahulu di lokasi yang rawan anak jalanan, gepeng dan pengamen seperti di perempatan lampu merah, di bawah fly over, dsb. Selain itu, Dinsosnangkis juga terbantu dengan adanya informasi dari masyarakat mengenai keberadaan anak jalanan, gepeng dan pengamen di daerah sekitarnya masing-masing.

\section{PENUTUP}

\section{Kesimpulan}

Implementasi Undang-undang Nomor 23

Tahun 2002 tentang Perlindungan Anak mengenai pembinaan anak jalanan pada Dinas Sosial dan Penanggulangan Kemiskinan Kota Bandung, belum mampu diterapkan secara efektif karena dari tujuan dan sasaran dari peraturan Undang-undang Nomo 23 Tahun 2002 belum ada yang dapat tercapai secara maksimal. Kemudian, sumber daya dari Dinsosnangkis sendiri masih terbilang kurang.

Dan masyarakat juga masih kurang berperan aktif dalam mendukung penerapan kebijakan ini, terbukti masih banyak orang yang justru memberikan uang kepada anak jalanan dengan alasan kasihan maupun agar mereka cepat pergi dan tidak mengganggu. Padahal sudah jelas ada larangan dan himbauan dari pemerintah kepada masyarakat agar tidak memberikan uang terhadap anak jalanan atau gelandangan di jalanan.

\section{DAFTAR PUSTAKA}

[1] Abdul Wahab, Solichin. (1997). Evaluasi Kebijakan Publik, Malang: FIA UNIBRAW dan IKIP Malang.

[2] Alm, Aten and Bahn. (2001). "Can Indonesia Decentralise Successfully? Plan Problem, and Prospects", Bulletin of Indonesian Economic Studies, 37(1),83-102.

[3] Agustino, Leo. (2006). Dasar-dasar Kebijakan Publik, Bandung: Alfabeta.

[4] Beaumont, E. (2001). "Policy and Administration: One More Time in Frying Pan", International Journal of Public Administrtion, 24(1)

[5] Bjur, W.E. and Zomorrodian, A. (1986). "Towards Indigenous Theories of Administration: An International Perspective", International Review of Administration Sciences, 52(4), 504-509.

[6] Denhardt, RB \& Denhardt, JV. (2000). "The New Public Service", Public Adinistration Review, 60(6),320-331.

[7] Dess Gregory G. (2012). Strategic Management Text and Cases Sixth Edition. New York: The McGraw-Hill.

[8] Devas, N. (1997). "Indonesia: what do we mean by Decentralization?, Public Administration and Development, 17,351367.

[9] Dunn, William. N. (2000). Analisis Kebijaksanaan Publik, Yogyakarta: Gadjah Mada University press.

[10]Ekowati, Mas Roro Lilik. (2005). Perencanaan, Implementasi dan Evaluasi Kebijakan atau Program (Suatu kajian Teoritis dan Praktis). Surakarta: Pustaka Cakra.

[11]Engkus. (2017). Administrasi Kepegawaian Indonesia Pada Sektor Publik (Dalam Pendekatan Aparatur Sipil Negara). Bandung: FISIP UNPAS PRESS.

[12]Engkus.(2017) "Implementasi Undangundang Perdagangan : Implikasinya Dalam Kebijakan Pengendalian Harga Kebutuhan Pokok Masyarakat", Jurnal LITIGASI 18 (1). pp. 1-44. 
[13]Engkus. (2017) "Budaya Panengen Sebagai Representasi Simbolik Kepemimpinan Desa Cikalong". Jurnal Ilmiah seni dan budaya Panggung, 27 (2). Pp.20-35.

[14] Engkus. (2017). "Perilaku Narsis Pada Media Sosial Di Kalangan Remaja Pelajar dan Upaya Penanggulangannya di Wilayah Bandung Timur. Jurnal Penelitian Komunikasi, 20( 2).30-52

[15]Engkus, E. (2013). Desentralisasi (Teori yang Baik dengan Praktek yang buruk), JISPO: Jurnal Ilmu Sosial dan Ilmu Politik, (4), 1-16.

[16]Engkus, E. (2017). The Influence Of organizational Behavior On Work Ethics Employees In Bandung Regency Goverment, IASET, 1 (1). 1-16.

[17]Islmamy, M Irfan. (2002). Prinsip-Prinsip Perumusan Kebijakan Negara. Jakarta: Bumi Aksara.

[18] Kaho, Josef Riwu. (2010). Prospek Otonomi Daerah di Negara Republik Indonesia. Jakarta: Raja Grafindo Persada.

[19]La Porte, T., Demchak, C., \& de Jong, M. (2002). "Democracy and Bureaucracy in The Age of The Web: Empirical Findings and Theoretical Speculations", Administration and Society, 24 (4)

[20]Lele, Gabriel. (2012). The Paradox of Distance in Decentralized Indonesia. Jurnal Ilmu Sosial dan Ilmu Politik. 15 (3).

[21]Lonti, Z and Verma, A. (2003). "The Determinant Flexibility and Innovation in The Government Workplace: Recent Evident from Canada", Journal of Public Administation Research and Theory, 13 (3), 283-310.

[22]Mardiasmo. (2004). Otonomi dan Manajemen Keuangan Daerah. Yogyakarta: ANDI.

[23] Moncrieffe, JM. (2001). “Accountability: Idea, Ideal, Constraint", Democratization, $8(3), 26-50$.

[24]Nawawi, Ismail. (2009). Public Policy, Analisis, Strategi Advokasi Teori dan Praktek. Surabaya: PMN.
[25]Nugroho, Riant. (2011). Public Policy. Jakarta: Gramedia.

[26]Prasad, K.G.K. (2002). 'Development through Information Technology in Developing Countries: Experiences from an Indian State", The Electronic Journal Information System in Developing Countries, 8(2).

[27]Rachmawati, Tutik. (2016). Metode Pengumpulan Data Dalam Penelitian Kualitatif. Bandung: CPPMS FISIP UNPAR.

[28] Singarimbun, Masri. (1994). Metode Penelitian Survai. Jakarta: LP3ES.

[29] Siagian, Sondang P. (2001). Kerangka Dasar Ilmu Administrasi. Jakarta: Rineka Cipta.

[30] Siagian, Sondang P. (1990). Filsafat Administrasi. Jakarta: Haji Masagung.

[31] Siagian, Sondang P. (2014). Administrasi Pembangunan Konsep, Dimensi, dan Strateginya. Jakarta: Bumi Aksara.

[32] Silalahi, Ulbert. (2013). Asas-Asas Manajemen. Bandung: Refika Aditama.

[33] Silalahi, Ulbert. (2013). Studi Tentang Administrasi: Konsep, Teori, dan Dimensi. Bandung: Sinar Baru Algensindo.

[34] Situmorang, Victor Mdan Juhir, Jusuf. (1998). Aspek Hukum Pengawasan Melekat. Jakarta: Rineka Cipta.

[35] Sugiyono. (2008). Metodologi Penelitian Bisnis (Pendekatan Kuantitatif, Kualitatif, Dan $R \& D)$. Bandung: Alfabeta.

[36] Sugiyono. (2009). Metode Penelitian Bisnis (Pendekatan Kuantitatif, Kualitatif, dan R \& $D)$, Bandung: Alfabeta.

[37] Sugiyono. (2011). Metode Penelitian Kuntitatif Kualitatif dan $R \& D$, Bandung: Alfabeta.

[38] Suparman, Nanang. (2017). Kualitas Pelayanan Izin Mendirikan Bangunan (IMB) Pada Badan Pelayanan Perizinan Terpadu Dan Penanaman Modal Kabupaten Cianjur, Jurnal Administration. 13(1).pp.1-88.

[39] Vigoda, E.(2000). "Are you being served? The Responsiveness of Public administration to citizens' demands: An empirical 
examination in Israel. Public Administration, 78(1), 165-191.

[40] Wibawa Samodra dan Muluk MR Khairul. (2009). Administrasi Negara; Isu-isu Komtemporer. Yogyakarta: Graha Ilmu.

[41] Wicaksono, Kristian Widya. (2014). Telaahan Kritis Administrasi \& Manajemen Sektor Publik. Bandung: Gava Media.

[42] Widjaja, HAW. (2007). Otonomi Daerah dan Daerah Otonom. Jakarta: Raja Grafindo Persada.

[43] Widjaja, HAW. (2014). Otonomi Daerah dan Daerah Otonom. Jakarta: Raja Grafindo Persada.

[44]Zouridis, S.(2002). "From Street-Level to System-Level Bureaucracies: How Information and Communication Technology in Transforming Administrative Discretion and Constitutional Control", Public Administration Review, 62(2). 
HALAMAN INI SENGAJA DIKOSONGKAN 